\title{
Spatio-temporal variability of inorganic and organic nutrients in five Galician rias (NW Spain)
}

\author{
MARÍA DOLORES DOVAL, ADELA LÓPEZ and MILAGROS MADRIÑÁN \\ Instituto Tecnológico para el Control del Medio Marino de Galicia (INTECMAR), Peirao de Vilaxoán, \\ E-36611 Vilagarcía de Arousa, Spain. E-mail: mdoval@intecmar.org
}

\begin{abstract}
SUMMARY: The spatial variability of inorganic (nitrate, nitrite, ammonium, phosphate and silicate) and organic (dissolved organic carbon) nutrients in five Galician rias (Vigo, Pontevedra, Arousa, Muros and Ares-Betanzos) was assessed by considering average values for the upwelling and downwelling periods. Inner stations were significantly different from middle and outer stations, especially during the downwelling period. Spatial differences between the five rías, tested by means of a multivariate analysis, were found in both periods. The behaviour of inorganic and organic nutrient variables was also significantly different between periods with and without shellfish harvesting closures due to the occurrence of toxic phytoplankton species.
\end{abstract}

Keywords: coastal upwelling, nutrient salts, dissolved organic carbon, ria, shellfish harvesting closures.

RESUMEN: VARIABILIDAD ESPACIO-TEMPORAL DE LOS NUTRIENTES INORGÁNICOS Y ORGÁNICOS EN CINCO RÍAS GALLEGAS (Noroeste España). - La variación espacial de los nutrientes inorgánicos (nitrato, nitrito, amonio, fosfato y silicato) y orgánicos (carbono orgánico disuelto) fue evaluado en las cinco rías gallegas (Vigo, Pontevedra, Arousa, Muros y AresBetanzos), considerando los valores medios para los periodos de afloramiento y hundimiento. Las estaciones estuáricas se separaron significativamente de las estaciones intermedias y oceánicas, especialmente durante el periodo de hundimiento. Se encontró para ambos periodos una variabilidad espacial entre las cinco rías, comprobada mediante análisis multivariante. El comportamiento de los nutrientes inorgánicos y orgánicos fue significativamente diferente cuando comparamos periodos con y sin cierres debidos a eventos o episodios de fitoplancton tóxico.

Palabras clave: afloramiento costero, sales de nutrientes, carbono orgánico disuelto, ría, cierres de bateas.

\section{INTRODUCTION}

The coastal ocean, which represents $<10 \%$ of the surface and $<1 \%$ of the volume of the global ocean, is responsible for $18-33 \%$ of the primary production of the global ocean (Wash 1991, Wollast 1998). The Galician coast is at the northern limit of the NW Africa upwelling system, which extends from $10^{\circ} \mathrm{N}$ to $44^{\circ} \mathrm{N}$ (Wooster et al. 1976). In this area, coastal winds are favourable to the upwelling of cold, inorganic nutrientrich and organic nutrient-poor waters during spring and summer and the downwelling of warm, inorganic nutrient-poor and organic nutrient-rich surface coastal waters during autumn and winter (Wooster et al. 1976, Alvarez-Salgado et al. 2000). Inorganic and organic nutrients from upwelling pulses, freshwater inputs and the mineralisation of organic matter fuel the phytoplankton activity that supports this highly productive coastal ecosystem.

The Galician coast (NW Spain) is occupied by several embayments of varying sizes, orientations and river discharges that are freely connected with the adjacent shelf, called rías. Four large coastal indentations of more than $2.5 \mathrm{~km}^{3}$ (Rías Baixas) and a medium sized embayment of $0.75 \mathrm{~km}^{3}$ (Ría de Ares-Betanzos) occupy the NW area of the Galician coast. The five rías, which are like partially stratified estuaries, are important sites for the extensive farming of shellfish, especially the blue mussel Mytilus galloprovincialis. Recurrent closures of mussel farms in this area have 
been due to paralytic shellfish poisoning (PSP), diarrheic shellfish poisoning (DSP), and amnesic shellfish poisoning (ASP). Gymnodinium catenatum and Alexandrium minutum for PSP, Dynophysis acuminata and Dynophysis acuta for DSP, and Pseudo-nitzschia spp. for ASP, are the main species responsible for these toxic events.

Oceanographic conditions dictate the proliferation of microplankton species. Some studies have analysed the relationship between the occurrence of Harmful Algal Bloom (HAB) species and inorganic nutrients in the sea (Smayda 1990, Anderson et al. 2002), and there are a few reports on organic nutrients (Graneli et al. 1999, Glibert et al. 2005). In addition, other oceanographic parameters such as the upwelling index can be used directly to study shellfish harvesting closures (Alvarez- Salgado et al. 2008).

Previous studies have made it possible to infer the spatio-temporal variability and dynamics of inorganic and organic nutrients, especially in the rías of Vigo and Arousa (Fraga 1967, Alvarez-Salgado et al. 1996, Doval et al. 1998, Prego et al. 1999, Alvarez-Salgado et al. 2001). However, there are no studies on the spatial variability of inorganic and organic nutrients for the five main Galician rías simultaneously.

In this study, the spatial variability of inorganic (nitrate, nitrite, ammonium, phosphate and silicate) and organic (dissolved organic carbon) nutrients and their elemental ratios were assessed for the main rías of Galicia, considering the average upwelling and downwelling periods of four consecutive years (2004-2007). In addition, the inorganic and organic nutrient status in the surface mixed layer during similar periods, with and without shellfish harvesting closures, were compared in the same areas.

\section{MATERIALS AND METHODS}

\section{Study site}

The four coastal embayments collectively known as Rías Baixas (Vigo, Pontevedra, Arousa and Muros) and the central Ría de Ares-Betanzos are currently sampled weekly to monitor their oceanographic conditions. The Oceanographic Monitoring Programme carried out by the Technological Institute for Marine Environment Control of the Xunta de Galicia (INTECMAR) has maintained an extensive network of 38-41 oceanographic stations since 1992.

Data from 38 oceanographic stations sampled from 2004 to 2007 were used here to study the inorganic and organic nutrient distribution. The position of each oceanographic station is shown in Figure 1, coded as $\mathrm{V}$ or $\mathrm{B}$ for ría de Vigo, $\mathrm{P}$ for ría de Pontevedra, A for ría de Arousa, $\mathrm{M}$ for ría de Muros and $\mathrm{L}$ for ría de Ares-Betanzos.
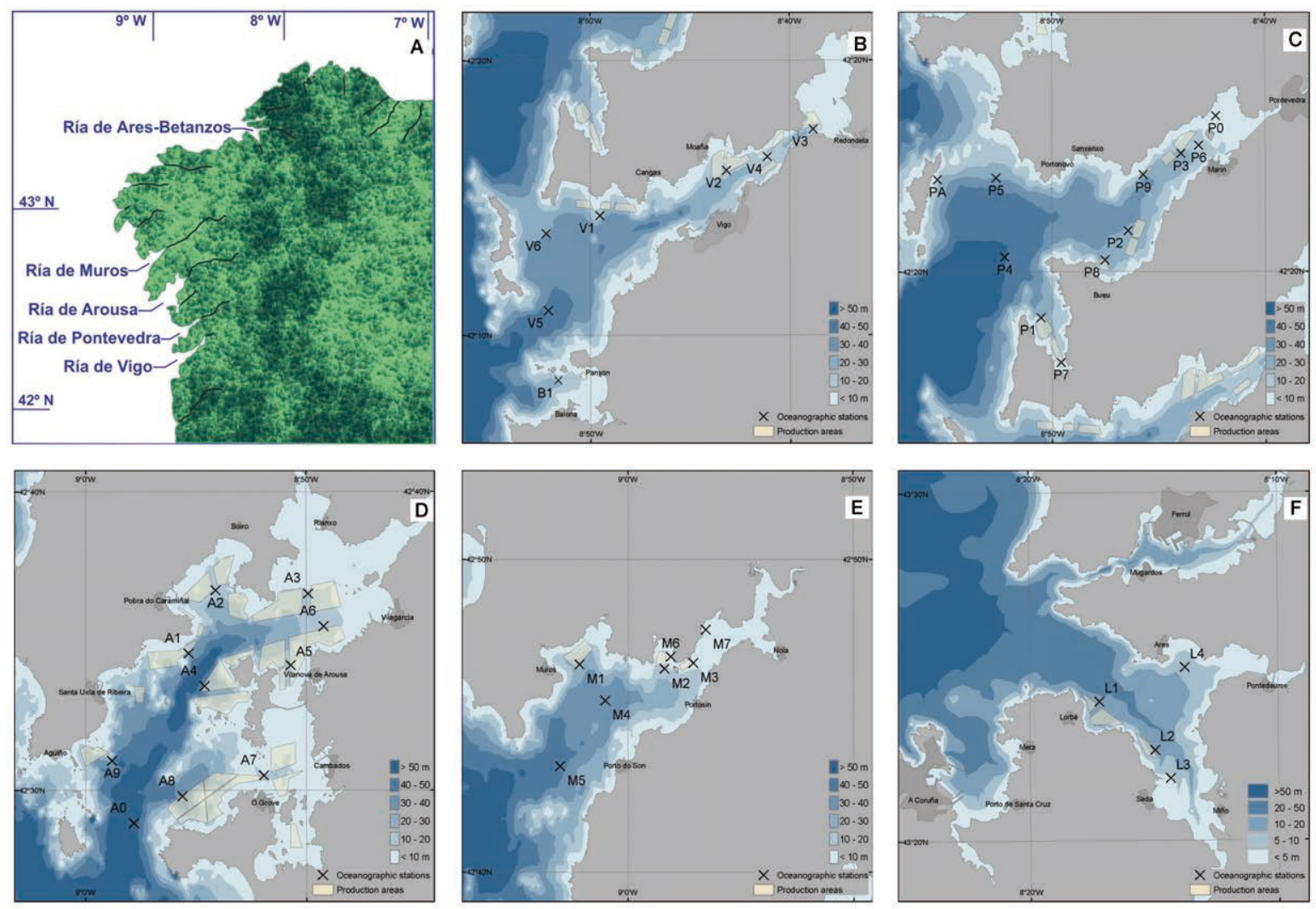

FIG. 1. - Sampling locations. A, overview of the Galician coast (NW Spain); B, ría de Vigo; C, ría de Pontevedra; D, ría de Arousa; E, ría de Muros; and F, ría de Ares-Betanzos. 
To study the spatial variability within the rías, the oceanographic stations were grouped into three categories. Inner stations correspond to the inner side of the rías, with water depths $<20 \mathrm{~m}$ (V2, V3, V4, P0, P3, P6, A2, A3, A5 and A6) or <12 m (M3, M6, M7, L2, L3 and L4). Outer stations are located at the mouth of each ría (V5, V6, P4, P5, A0, A8, A9, M5 and $\mathrm{L} 1$ ), and middle stations are in intermediate areas (V1, B1, P1, P2, P7, P8, P9, A1, A4, A7, M1, M2 and M4).

\section{Measured variables}

Seawater samples were taken with $1.7 \mathrm{~L}$ Niskin bottles to measure surface (1 $\mathrm{m}$ deep) dissolved organic carbon (DOC), which is determined with a Shimadzu TOC-V by high temperature catalytic oxidation (HTCO). The precision is $\pm 0.8 \mu \mathrm{mol} \mathrm{L}^{-1}$. The accuracy was tested with the reference materials provided by Prof. D. Hansell (Univ. of Miami). We obtained an average concentration of $45.3 \pm 2.4 \mu \mathrm{mol} \mathrm{L}^{-1}(\mathrm{n}=91)$ for batch $3,44.2 \pm 1.7 \mu \mathrm{mol} \mathrm{L}^{-1}(\mathrm{n}=92)$ for batch 6 and $41.9 \pm 1.8 \mu \mathrm{mol} \mathrm{L}^{-1}(\mathrm{n}=45)$ for batch 7 of the deep ocean reference batches minus blank reference materials. The nominal TOC values provided by the reference laboratory were $45 \pm 1 \mu \mathrm{mol} \mathrm{L}^{-1}, 45 \pm 1 \mu \mathrm{mol} \mathrm{L}^{-1}$ and $42.5 \pm 1.5$ $\mu \mathrm{mol} \mathrm{L}-1$ respectively.

Sampling for the analysis of inorganic nutrients (nitrate, nitrite, ammonium, phosphate and silicate) was performed using a PVC hose that collects water from three depth intervals $(0-5 \mathrm{~m}, 5-10 \mathrm{~m}$ and $10-15$ $\mathrm{m})$. Analytical techniques were based on colorimetric methods of continuous segmented flow analysis (CFA), initially proposed by Hansen and Grassoff (1983) and modified by Bran-Luebbe for the Quaatro analyser. The precisions are $\pm 0.02 \mu \mathrm{mol} \mathrm{L}^{-1}$ for nitrite, $\pm 0.1 \mu \mathrm{mol} \mathrm{L}^{-1}$ for nitrate, $\pm 0.05 \mu \mathrm{mol} \mathrm{L}{ }^{-1}$ for ammonium, $\pm 0.01 \mu \mathrm{mol} \mathrm{L}^{-1}$ for phosphate and $\pm 0.06 \mu \mathrm{mol}$ $\mathrm{L}^{-1}$ for silicate. Their accuracies were tested daily with the reference materials provided by Quality Assurance of Information for Marine Environmental Monitoring in Europe (QUASIMEME) exercises for inorganic nutrients. The performance of all reference materials must be satisfactory $(|z|<2$, Thompson and Wood 1993). In addition, dissolved inorganic nitrogen (DIN: nitrate+nitrite + ammonium) and the ratios between DIN and silicate $\left(\mathrm{DIN} / \mathrm{SiO}_{4}\right)$ and phosphate $\left(\mathrm{DIN} / \mathrm{PO}_{4}\right)$ were considered.

All inorganic and organic nutrient analyses were accredited by ENAC, Norm UNE-EN ISO/IEC 17025:2005.

At each oceanographic station a CTD SBE 25 was lowered into the water column to obtain vertical profiles of the salinity (pss) and temperature $\left({ }^{\circ} \mathrm{C}\right)$. We only consider here the averages values of the upper $15 \mathrm{~m}$, where nutrients were studied, in certain time periods. These distributions can be found at the INTECMAR website (www.intecmar.org) and in Pazos et al. 2008 and Doval et al. 2009.

\section{Statistical analyses}

Statistics were performed with the Minitab 15 statistical package. A Principal Component Analysis (PCA) with two components was used to interpret the covariance structure in the original variables considering average values for the five rías. A Discriminant Analysis (DA) was used to test for significant differences between the five rías considered, to determine which variables contribute to group separation and also to classify stations into each group, considering all stations of each ría.

To study the spatial variability among the five rías, average values between 2004 and 2007 of the oceanographic stations in each ría were considered.

A PCA with two components was used to interpret the covariance structure in the original variables considering periods with and without shellfish harvesting closures for the same areas. A DA could not be used here because at least two cases for each group are necessary.

It was not necessary to transform the variables in either of the multivariate analyses.

\section{RESULTS}

\section{Spatial distribution of nutrients during the upwelling period}

Average values of inorganic and organic nutrients for the upwelling period (April-September) from 2004 to 2007 were considered in order to study the inter- and intra-ría spatial variability.In the outer and middle stations a relative DOC maximum was observed. Nitrate, ammonium, phosphate and $\mathrm{DIN} / \mathrm{SiO}_{4}$ ratio minima were found in the Ría de Ares-Betanzos, a relative silicate maximum was observed in the Ría de Arousa and a relative DIN/ $\mathrm{PO}_{4}$ ratio maximum in the Ría de Muros (Fig. 2). The inner stations showed higher DOC, ammonium, phosphate and silicate values and lower DIN/ $\mathrm{SiO}_{4}$ ratios than the outer stations during this period (Fig. 2). A north-south gradient of nutrients was also observed in the middle to outer segment of some rías. Relative maxima of all inorganic and organic nutrients were recorded on the southern margin of the Ría de Pontevedra (stations P2, P8 and P4) in comparison with the northern margin of this ría (station P5).

To illustrate the distribution of the spatial variability (Fig. 2), box whisker-plots of the DOC, phosphate, $\mathrm{DIN} / \mathrm{SiO}_{4}$ ratio and nitrate are shown (Fig. 3). The average of these four variables was significantly different (T-test, $\mathrm{p}<0.1$ ) among the five rías.

A PCA with two components was used first to study the spatial variability between rías. For this period, a PCA for all stations (case a) within each ría produced better results (the retained first two components explained $91.4 \%$ of the total variance, Table 1) than when only middle and outer stations (case b) were considered $(83 \%)$. For case a, the first component (which explained 

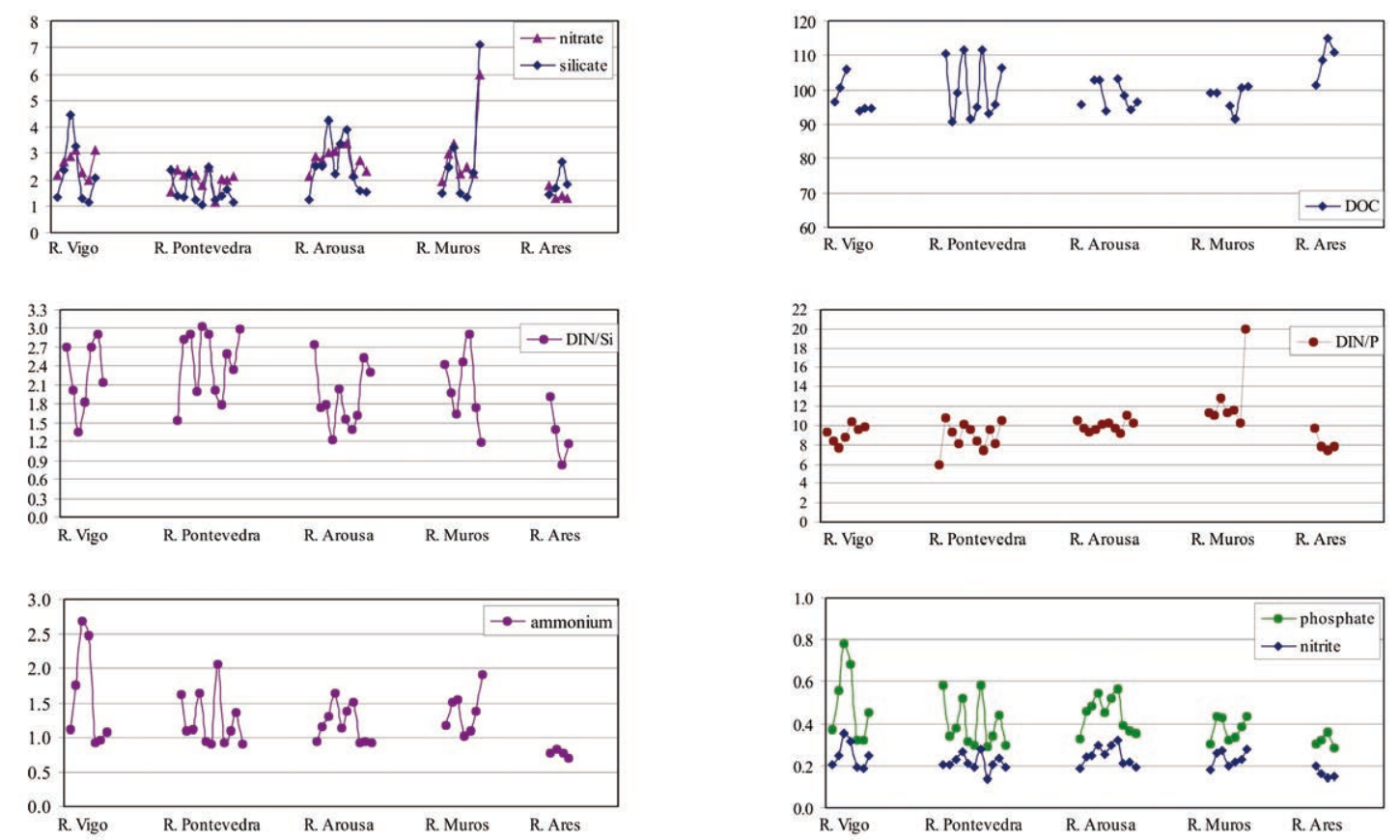

FIG. 2. - Distribution of the average nitrate, silicate, $\mathrm{DIN} / \mathrm{SiO}_{4}$ ratio, ammonium, DOC, DIN/PO $/$ ratio, nitrite and phosphate during the upwelling period (April-September) of all oceanographic stations of the five rías. Oceanographic stations are ordered by name within each ría. Units in $\mu \mathrm{mol} \mathrm{L}-1$
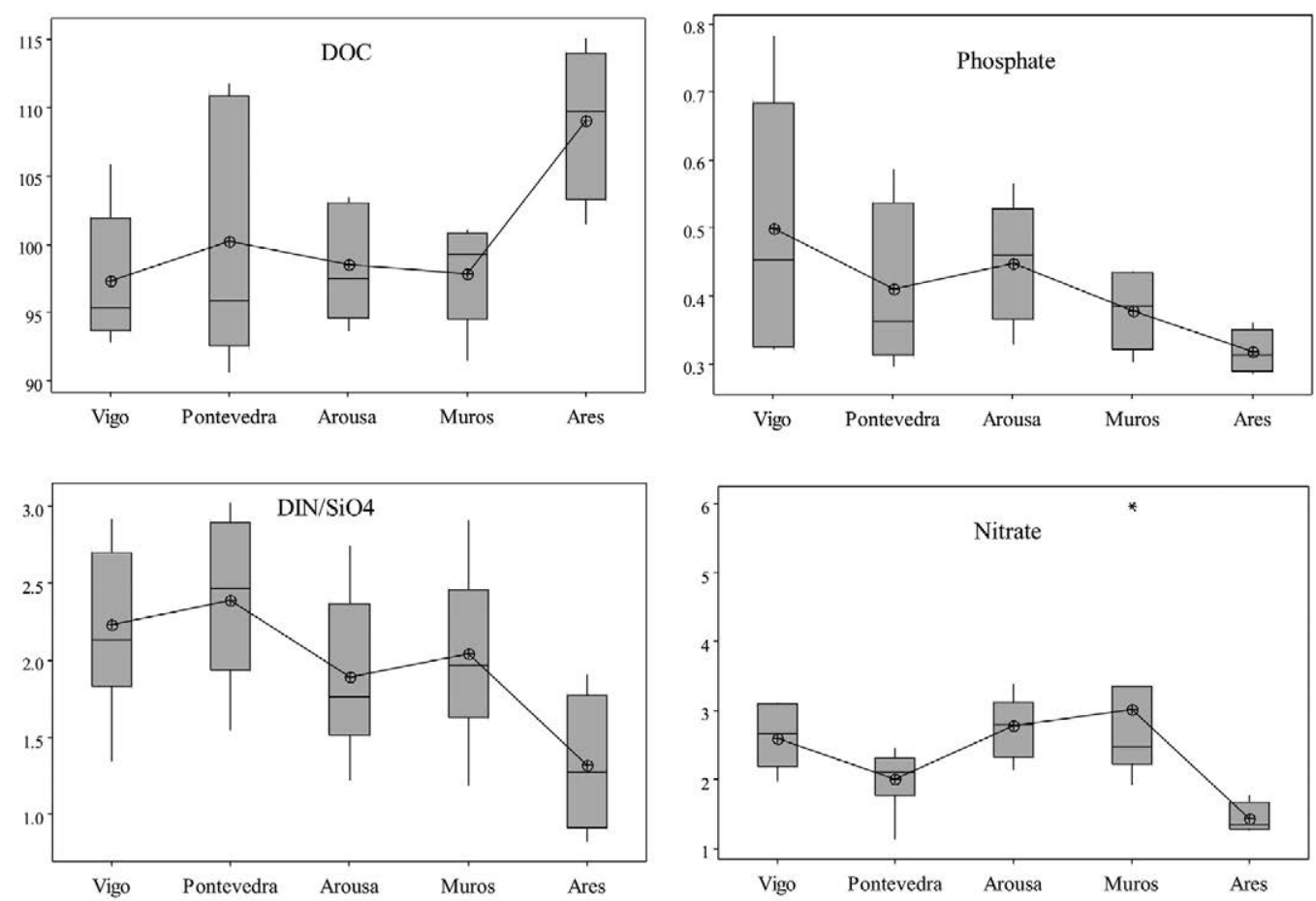

FIG. 3. - Distribution of box-whisker plots of DOC, phosphate, $\mathrm{DIN} / \mathrm{SiO}_{4}$ ratio and nitrate during the average upwelling period. Interquartile range, outlier symbols and mean connect line are shown. Units in $\mu \mathrm{mol} \mathrm{L}^{-1}$.

$69 \%$ of the total variance) was mainly related to DIN, DOC, nitrite, nitrate, temperature and ammonium. The second component (which explained $22.3 \%$ of the total variance) was mainly related to salinity, silicate, the $\mathrm{DIN} / \mathrm{PO}_{4}$ ratio and the $\mathrm{DIN} / \mathrm{SiO}_{4}$ ratio. The score plot was similar for both cases. The rías of Muros and Arousa were related to positive $\mathrm{PC} 1$ scores and negative $\mathrm{PC} 2$ scores, the Ría de Vigo was related to positive scores of both PC1 and PC2, the Ría de Pontevedra was related to negative PC1 scores and positive PC2 scores and the Ría 
TABLE 1. - Loading of the variables of the Principal Component Analysis with two components for all oceanographic stations during the average upwelling and downwelling periods and during different closure periods due to ASP, PSP and DSP toxins.

\begin{tabular}{|c|c|c|c|c|c|c|c|c|c|c|c|c|}
\hline & \multicolumn{2}{|c|}{ upwelling } & \multicolumn{2}{|c|}{ downwelling } & \multicolumn{2}{|c|}{ ASP } & \multicolumn{2}{|c|}{ PSP-A. minutum } & \multicolumn{2}{|c|}{ DSP-D. acuta } & \multicolumn{2}{|c|}{ DSP-D. acuminata } \\
\hline & PC1 & $\mathrm{PC} 2$ & $\mathrm{PC} 1$ & PC2 & PC1 & $\mathrm{PC} 2$ & PC1 & $\mathrm{PC} 2$ & PC1 & PC2 & PC1 & PC2 \\
\hline op & 0.69 & 0.223 & ? & 0.2 & 0.539 & 0.410 & 0.640 & 0.2 & 0.551 & 0.449 & 0.611 & 0.389 \\
\hline & 0 & 0 & & 0 & 0.270 & & 7 & -0.0 & & -0.2 & 11 & -0.286 \\
\hline phosphate & 0.281 & 0.277 & 0.124 & 0.485 & 0.256 & 0.363 & 0.191 & 0.462 & 0.202 & 0.391 & 0.382 & 0.066 \\
\hline nitra & 0.341 & -0.213 & 0.384 & -0.140 & -0.235 & 0.375 & 0.350 & -0.2 & 0.2 & 0. & 0.384 & -0.053 \\
\hline itri & 0.344 & 0.046 & 0.346 & 0.217 & 0.097 & 0.454 & 0.354 & 0.1 & 0.4 & -0.0 & 0.366 & 0.152 \\
\hline silica & 0.224 & -0.473 & 0 & -0.046 & -0.333 & 0.2 & 0.329 & 0.2 & 0.3 & 0.0 & -0 . & 0.242 \\
\hline DIN/P & 0.229 & -0.441 & 0 & -0.298 & -0.373 & -0.113 & 0.2 & -0.3 & 0. & -0.3 & -0.254 & -0.364 \\
\hline DIN/Si & 0.260 & 0.358 & -0.381 & -0.018 & 0.368 & -0.128 & 0.226 & -0.447 & -0.405 & -0.025 & 0.343 & -0.221 \\
\hline 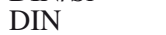 & 0.35 & -0.1 & & -0.0 & -0.095 & & & -0 . & & & 0.350 & -0.204 \\
\hline DOC & -0.356 & -0.101 & -0.166 & -0.424 & 0.352 & -0.198 & 0.290 & -0.092 & -0.093 & -0.438 & -0.204 & 0.410 \\
\hline 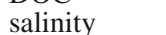 & 0.203 & 0.510 & -0.344 & 0.256 & 0.407 & -0.025 & 0.123 & & -0.3 & 0.3 & & 0.454 \\
\hline temperature & -0.333 & 0.169 & -0.096 & 0.254 & 0.337 & 0.234 & -0.371 & 0.501 & 0.122 & -0.429 & -0.020 & -0.483 \\
\hline
\end{tabular}

${ }^{1}$ proportion of total variance explained by each of the two components of each PCA.

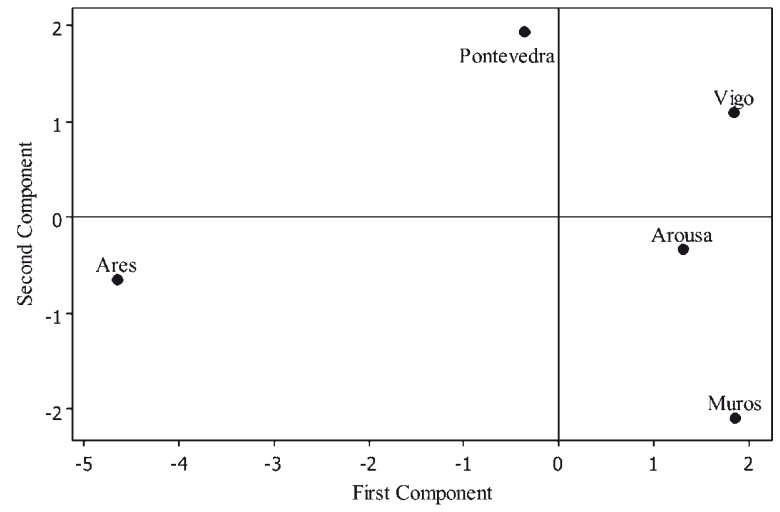

FIG. 4. - Score plot of the rías for the upwelling period considering all oceanographic stations.
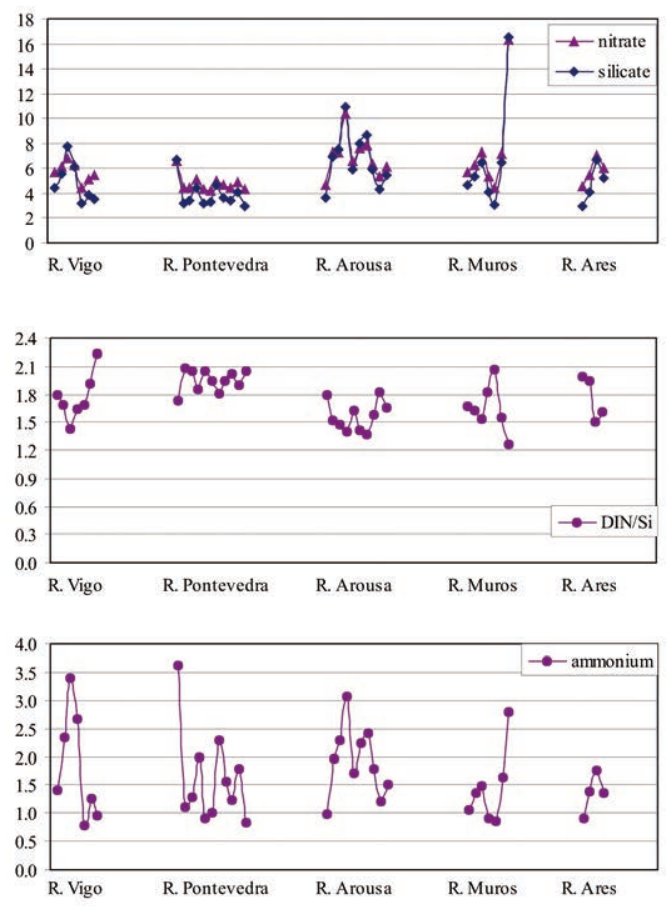

de Ares-Betanzos was related to negative scores of both PC1 and PC2. Figure 4 shows the score plot for case a.

A DA correctly classified 31 of 34 stations in their respective group (ría), which is a correct proportion of $91.2 \%$, using the predictors (variables) of ammonium, phosphate, nitrate, nitrite, $\mathrm{DIN} / \mathrm{PO}_{4}$ ratio, $\mathrm{DIN} / \mathrm{SiO}_{4} \mathrm{ra}-$ tio, DOC, salinity and temperature. The misclassified stations were V5, V6 and P0.

\section{Spatial distribution of nutrients during the downwelling period}

Average values of nutrients for the downwelling period (October-March) from 2004 to 2007 were considered again to study the inter- and intra-ría spatial variability.
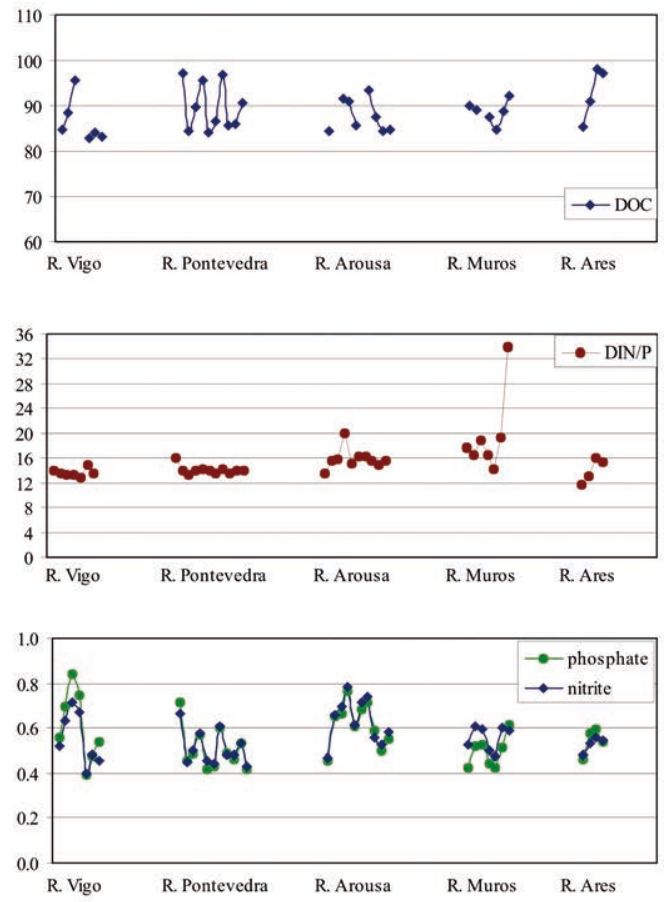

FIG. 5. - Distribution of the average nitrate, silicate, $\mathrm{DIN} / \mathrm{SiO}_{4}$ ratio, ammonium, DOC, DIN/PO $/$ ratio, nitrite and phosphate during the downwelling period (October-February) for all oceanographic stations of the five rías. Oceanographic stations are ordered by name within each ría. Units in $\mu \mathrm{mol} \mathrm{L} \mathrm{L}^{-1}$ 

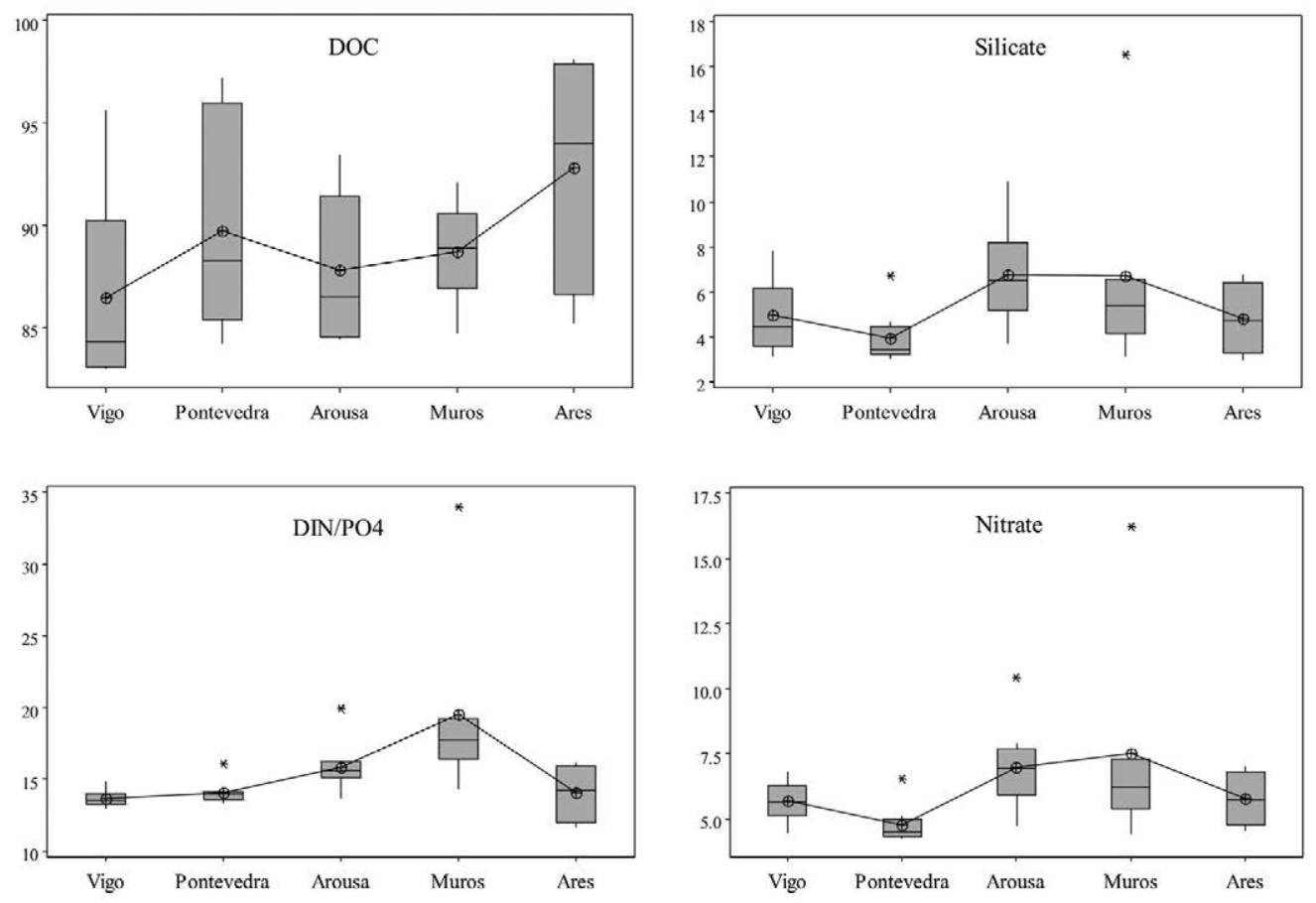

FIG. 6. - Distribution of the box-whisker plots of DOC, silicate, DIN/P ratio and nitrate during the average downwelling period. Interquartile range, outlier symbols and mean connect line are shown. Units in $\mu \mathrm{mol} \mathrm{L}-1$

Considering the outer and middle stations, a relative silicate and $\mathrm{DIN} / \mathrm{PO}_{4}$ ratio minimum was observed in the Ría de Ares-Betanzos and maxima of all inorganic nutrients in the Ría de Arousa (Fig. 5). The inner stations showed higher DOC, ammonium, phosphate, silicate, nitrate and nitrite values and lower DIN/SiO ratios than the outer station during this period (Fig. 5). A north-south gradient of nutrients was also observed in the middle to outer area of some rías. A relative maxima of all inorganic nutrients was recorded on the southern margin of the Ría de Pontevedra (stations P2, P8 and P4), on the northern margin of the Ría de Vigo (stations V6 and V1) and on the northern margin of the Ría de Arousa (station A9) in comparison with the northern margin of the Ría de Pontevedra (station P5), southern margin of Ría de Vigo (station V5) and southern margin of the Ría de Arousa (stations A0 and A8) respectively.

To illustrate the distribution of the spatial variability (Fig. 5), box whisker-plots of DOC, silicate, the DIN/ $\mathrm{PO}_{4}$ ratio and nitrate are shown (Fig. 6). The average of these four variables was significantly different (T-test, $\mathrm{p}<0.1$ ) among the five rías.

A PCA with two components was used first to study the spatial variability between rías. For this period, a PCA for all stations (case a) within each ría produced similar results (the retained first two components explained $84.3 \%$ of the total variance, Table 1) to when only middle and outer stations (case b) were considered $(85.8 \%)$. However, the proportion explained by each component and the variables related to each component differ a little between the two cases. For case a, the first component (which explained $57.2 \%$ of the total variance) was mostly related to DIN, silicate, nitrate, the $\mathrm{DIN} / \mathrm{SiO}_{4}$ ratio, nitrite and salinity. The second component (which explained $27.1 \%$ of the total variance) was mostly related to ammonium, phosphate and DOC. For case a (score plot, Fig. 7), the Ría de Arousa was related to positive scores of the PC1 and PC2, the Ría de Muros to positive PC1 scores and to negative PC2 scores, the Ría de Ares-Betanzos to negative scores of both components and the rías of Vigo and Pontevedra to negative PC1 scores and positive PC2 scores. For case b (score plot not shown), the rías of Vigo, Pontevedra, Muros and Ares-Betanzos slightly changed their position, and the Ría of Arousa showed the same behaviour.

A DA allowed us to correctly classify 32 of 34 stations in their respective group (ría), which is a correct proportion of $94.1 \%$, using the predictors (variables) of ammonium, phosphate, nitrite, DIN/PO $\mathrm{PO}_{4}$ ratio, DIN/ $\mathrm{SiO}_{4}$ ratio, DOC and temperature. The misclassified stations were $\mathrm{V} 6$ and $\mathrm{A} 0$.

\section{Nutrient distributions in relation to shellfish harvesting closures}

The distributions of nutrients in the surface mixed layer were considered in some areas and periods where toxic events with shellfish harvesting closures occurred during the years studied (2004-2007). These periods were reported by the ICES-IOC Working Group on Harmful Algal Bloom Dynamics (ICES WGHABD Reports 2005, 2006, 2007 and 2008) and can also be 


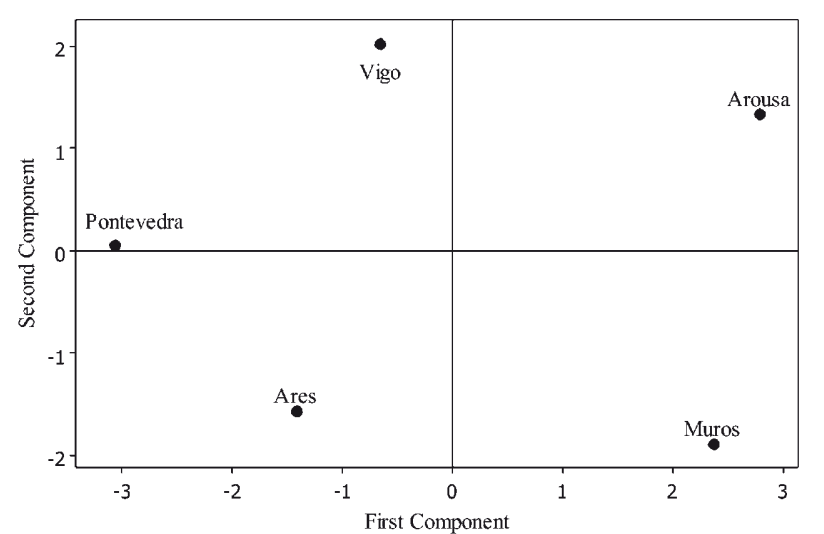

FIG. 7. - Score plot of the rías for the downwelling period considering all oceanographic stations

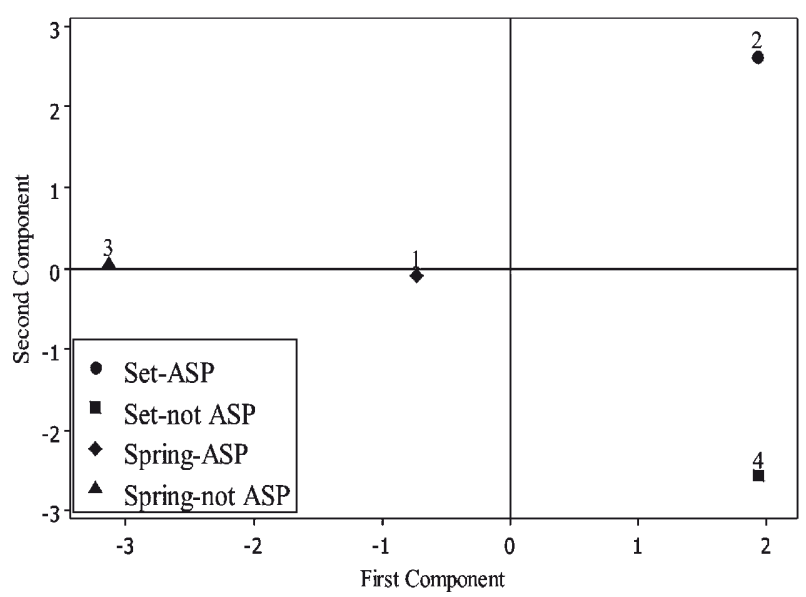

FIG. 8. - Score plot for periods related to shellfish harvesting closures due to ASP toxins (Pseudonitzschia spp).

found in the historic annual reports of shellfish harvesting closures published by the Biotoxins Department of INTECMAR (www.intecmar.org).

The significant correlations found between the average nutrients, salinity and temperature led us once more to use a PCA with two components.

\section{Shellfish closures due to ASP toxin (Pseudonitzschia spp.)}

This diatom causes recurrent shellfish closures in the Rías Baixas. To compare periods with and without shellfish harvesting closures, four situations were chosen: 1, closures in spring (March 04, May 05); 2, closures in September (September 04 and 06); 3 , opening period (not-ASP) in spring (March-May 07); and 4, opening period (not-ASP) in September (September 07).

The PCA for these four situations produced the following results: the retained first two components explained $95 \%$ of the total variance (Table 1). The first component (which explained $53.9 \%$ of the total variance) was mainly related to salinity, $\mathrm{DIN} / \mathrm{PO}_{4}$ ratio, $\mathrm{DIN} / \mathrm{SiO}_{4}$ ratio, DOC, temperature and silicate. The second component (which explained $41.0 \%$ of the total variance) was mainly related to DIN, nitrite, nitrate, phosphate and ammonium. The score plot (Fig. 8) separated the four situations as follows: situation 2 was related to positive scores of PC1 and PC2, situation 4 to positive PC1 scores and to negative PC2 scores, and situation 1 and 3 to negative PC1 scores.

\section{Shellfish closures due to PSP toxin (Alexandrium minutum)}

This dinoflagellate causes recurrent shellfish harvesting closures in the Ría de Ares-Betanzos. To compare periods with and without closures, four situations were chosen: 1, closures in spring (June 04, May 05); 2, closures in September (September 07); 3, opening periods (not-Alex) in spring (May-June 06, 07); and 4, opening periods (not Alex) in September (September 04, 05 and 06).

The PCA for these four situations produced the following results: the retained first two components explained $92.3 \%$ of the total variance (Table 1). The first component (which explained $64.0 \%$ of the total variance) was mainly related to DOC, DIN, nitrite, nitrate, ammonium and silicate. The second component (which explained $28.4 \%$ of the total variance) was mainy related to temperature, phosphate, $\mathrm{DIN} / \mathrm{SiO}_{4}$ ratio and DIN/ $\mathrm{PO}_{4}$ ratio. The score plot (Fig. 9) separated the four situations as follows: situation 4 was related to positive scores of $\mathrm{PC} 1$ and $\mathrm{PC} 2$, situation 2 to positive PC1 scores and to negative PC2 scores, situation 3 to negative scores of both components and situation 1 to negative PC1 scores and positive PC2 scores.

\section{Shellfish closures due to DSP toxin (Dinophysis acuta)}

This dinoflagellate causes sporadic shellfish closures in the Rías Baixas. To compare periods with and without closures, three situations were chosen: 1 , closure during the downwelling period due to DSP toxins (October 04-January 05, October-November 06); 2, closures due to DSP and PSP toxins during the down-

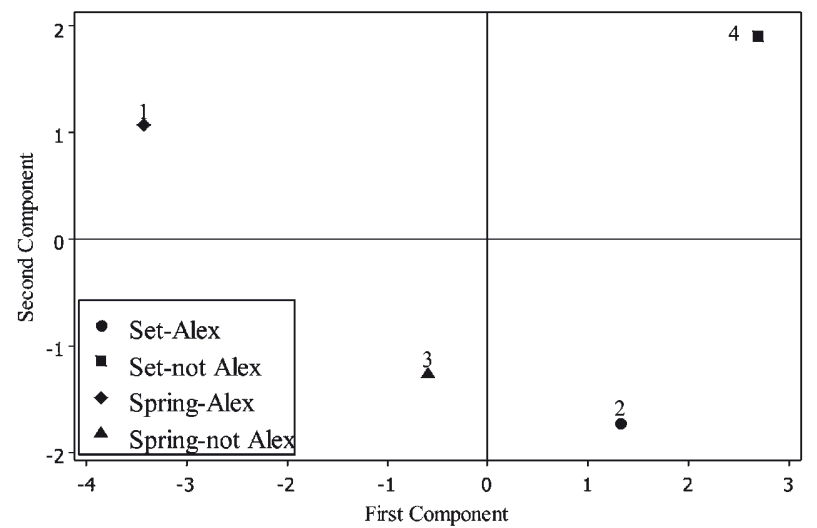

FIG. 9. - Score plot for periods related to shellfish harvesting closures due to PSP toxins (A. minutum). 


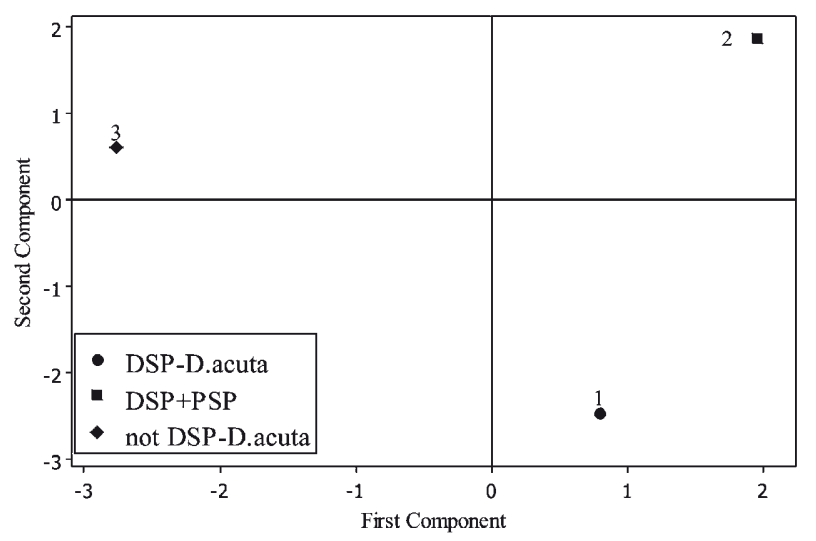

Fig. 10. - Score plot for periods related to shellfish harvesting closures due to DSP toxins (D. acuta).

welling period (October 05-January 06); and 3, opening periods (not DSP) during the downwelling period (October-December 07).

The PCA for these three situations produced the following results: the retained first two components explained $100.0 \%$ of the total variance (Table 1). The first component (which explained $55.1 \%$ of the total variance) was mainly related to the $\mathrm{DIN} / \mathrm{SiO}_{4}$ ratio, nitrite, silicate, and ammonium. The second component (which explained $44.9 \%$ of the total variance) was mainly related to DOC, temperature, phosphate and nitrate. The score plot (Fig. 10) separated the three situations as follows: situation 2 was related to positive scores of PC1 and PC2, situation 1 to positive PC1 scores and with negative PC2 scores and situation 3 to negative PC1 scores and positive PC2 scores.

\section{Shellfish closures due to PSP toxin (Gymnodinium catenatum)}

This dinoflagellate causes sporadic shellfish closures in the Rías Baixas. To compare periods with and without closures, three situations were chosen: 1 , closures in the downwelling period due to PSP and DSP toxins (October 05-January 06); 2, opening periods in

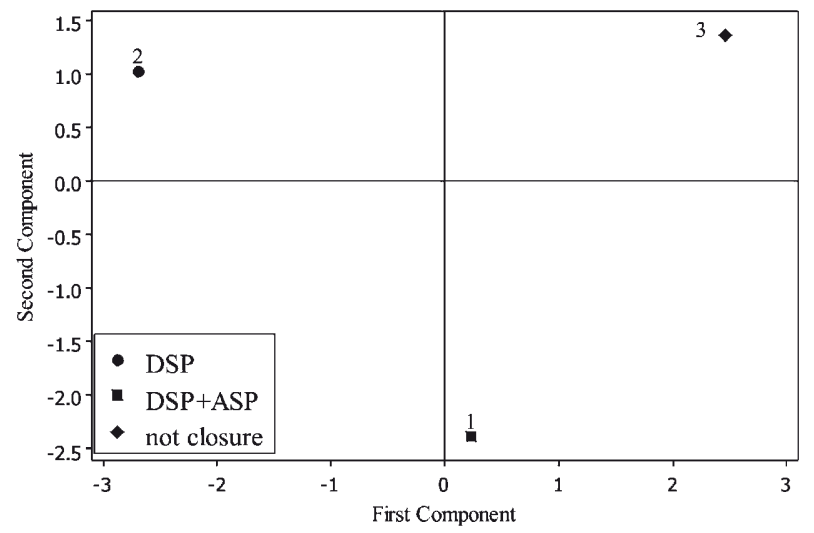

FIG. 11. - Score plot for periods related to shellfish harvesting closures due to DSP toxins (D. acuminata). the downwelling period due to PSP toxins (October 04-January 05, October-November 06 and OctoberDecember 07); and 3, opening periods not due to PSP or DSP (October-December 07). These three situations correspond to situations 2,1 and 3 , respectively of the previous case (DSP toxins due to D. acuta).

\section{Shellfish closures due to DSP toxin (Dinophysis acuminata)}

This dinoflagellate causes recurrent shellfish closures in the Rías Baixas. To compare periods with and without closures, three situations were chosen in the inner area of the Ría de Arousa (stations A1, A2, A3 and A6): 1, closures due to DSP and ASP toxins in spring (May-June 2005); 2, closures due to DSP toxin (JuneJuly07); and 3, opening periods (not DSP) in spring (May-July 04 and May-July 06).

The PCA for these three situations produced the following results: the retained first two components explained $100.0 \%$ of the total variance (Table 1). The first component (which explained $61.1 \%$ of the total variance) was mainly related to nitrate, phosphate, nitrite, DIN, DIN/SiO ${ }_{4}$ ratio and silicate. The second component (which explained $38.9 \%$ of the total variance) was mainly related to temperature, salinity, DOC and the DIN/PO $\mathrm{PO}_{4}$ ratio. The score plot (Fig. 11) separated the three situations as follows: situation 3 was related to positive scores of $\mathrm{PC} 1$ and $\mathrm{PC} 2$, situation 1 to positive PC1 scores and negative PC2 scores and situation 2 to negative PC1 scores and positive PC2 scores.

\section{DISCUSSION}

\section{Spatial variability of inorganic nutrients and DOC}

\section{Differences within the same ría}

Clear spatial differences can be observed in the circulation pattern of the Rías Baixas, in which the middle and outer segments are extensions of the shelf controlled by shelf wind stress, and the inner segments are estuaries controlled by continental runoff (Alvarez-Salgado et al. 2000). Inner stations showed higher average values of DOC, ammonium, phosphate and silicate and a lower $\mathrm{DIN} / \mathrm{SiO}_{4}$ ratio than outer stations during upwelling and especially during downwelling periods. Continental inputs and waters regenerated in the innermost part of the rías, the higher influence of pelagic and benthic remineralisation processes and diffusion from sediments (since only the upper $15 \mathrm{~m}$ of the water column is considered) can explain this difference.

Similar results were found for inorganic nutrients in the rías of Vigo and Arousa (Fraga, 1967, Prego 1993; Prego 1994, Alvarez-Salgado et al. 1996) and inorganic nutrients and DOC in the Ría de Vigo (Doval et al. 1998, Alvarez-Salgado et al. 2001). DOC distributions were related to temperature in the Ría de Vigo (Doval et al. 1997) and also to stability of water masses in the 
Ría de Pontevedra. In both cases, the inner stations showed the highest temperature, stability (quantified by means of Brunt-Väisälä frequency, $\mathrm{N}^{2}$ ) and DOC.

A north-south gradient was observed in the middle to outer area of the Ría de Pontevedra in both periods considered. In addition, a north-south gradient was observed at the mouth of rías of Vigo and Arousa during the downwelling period.

Hydrographic differences have been observed previously at the mouth of Ría de Vigo due to the interaction between the wind and the topography (Souto et al. 2003). Differences in the DOC were observed during the upwelling period of 2002 in the Ría de Pontevedra, which were related to the stability of the water column. Coastal morphology and bathymetry are responsible for generating circulation features such as retention zones in upwelling areas (Kudela et al. 2005). These features could accumulate dissolved and suspended matter, which could explain this lateral difference.

\section{Differences among the five rías}

The five rías are partially mixed embayments affected by upwelling (downwelling) processes, but they show some differences related to i) their different orientation and morphology (especially Ría de AresBetanzos), which affects the period and intensity of the upwelling processes, remineralisation of organic matter inside the rías and in the shelf-water and the characteristics of the upwelled water (Prego et al. 1999, Alvarez-Salgado et al. 2000); ii) the different length and volume defined as Ría de Arousa $>$ rías of Vigo and Pontevedra > Ría de Muros > Ría de AresBetanzos established by Fraga and Margalef (1979) and Prego et al. (1999); and iii) the amplification of the effect of upwelling in the shelf waters near the Rías Baixas by the remineralisation of the organic matter (Alvarez-Salgado et al. 2000).

The PCA for the upwelling and downwelling periods produced two first factors accounting for $>83 \%$ of the total variance. The first factor during the upwelling period seems to be more related to upwelled waters. The second component of this period and the first and second components of the downwelling period were influenced by the other processes that affect the distribution of nutrients (downwelling, river water, regeneration processes, among others). Average values of inorganic nutrients, DOC, salinity and temperature during the two main seasonal periods between 2004 and 2007 allowed us to separate the five rías studied (Figs 3 and 5). The main features obtained from the PCA plots of all stations were that i) the Ría de AresBetanzos was clearly apart from the other rías during the upwelling and downwelling periods (negative PC1 and PC2); and ii) the Ría de Muros was clearly apart from other rías during the downwelling period (positive $\mathrm{PC} 1$ and negative $\mathrm{PC} 2$ ).

The DA for the upwelling and downwelling periods classified stations ( $>30$ of 34 ) with a correct propor- tion higher than $91 \%$ and identified the most important variables for both periods. The DA and PCA plots corroborated the significant differences among the five rías.

Previously, a difference in inorganic nutrients between the Rías Baixas and the Rías Altas was proposed based on data from the Ría de Vigo and the Ría de Ares-Betanzos (Prego et al. 1999). The inorganic nutrient levels in the Ría de Are-Betanzos were lower than those off the Rías Baixas.

\section{Different behaviour of nutrients in periods with and without shellfish harvesting closures}

The results obtained in this section should be considered with caution since average values of periods, variables and areas were used to study the possible differences in nutrient concentrations between periods with and without shellfish harvesting closures. Average monthly variables were used: the month the closure began and the month when that area was opened for harvesting were considered. In addition, some events were considered in each period. In general, the whole ría was considered (although the entire ría is not affected by closures), except for DSP (due to D. acuminata), for which only the inner area of Ría de Arousa was considered.

The principal components analysis for the different periods considered produced two first factors accounting for $>87 \%$ of the total variance. The first and second factors of each period seem to be related to a mixture of all processes that dictate the distribution of nutrients.

Using these factors, it was possible to separate the periods with and without closures due to ASP along the Rías Baixas in September (related to positive and negative PC2, respectively), but not in spring. In addition, it was possible to separate the closure periods due to ASP in September and spring (related to positive and negative PC1, respectively). Regarding the periods with and without closure due to PSP toxins (A. minutum) in the Ría de Ares-Betanzos, it was possible to separate both periods in September (related to negative and positive PC2, respectively), both periods in spring (related to positive and negative PC2, respectively) and closures in September and spring (related to positive and negative PC1, respectively). Regarding the periods with and without closure due to DSP (D. acuta) in the Rías Baixas, it was possible to separate both periods (related to positive and negative PC1, respectively) and closure periods due to DSP and due to DSP and PSP (related to negative and positive $\mathrm{PC} 2$, respectively). Regarding the periods with and without closure due to DSP (D. acuminata) in the inner Ría de Arousa, it was possible to separate closure periods due to DSP and due to DSP and ASP (related to positive and negative $\mathrm{PC} 2$, respectively).

When an individual event (instead of the average of some events) is considered some results can change. Considering the six situations found for ASP toxin (re- 
sults not shown), it was not possible to separate events with and without closures in spring but it was possible to separate both situations in September and closures in spring and September. The same behaviour was found considering the eight situations found for PSP toxins (A. minutum).

The average nutrient levels found in some areas of the Galician rías affected by shellfish harvesting closures due to toxic events can provide some insights into how to improve predicting these episodes. The study of more events and more restricted areas could improve these predictions. It is known that inputs, quality and flux of both organic and inorganic nutrients can lead to the development and proliferation of many toxic species (Anderson et al. 2002, Glibert et al. 2005). The interdependence of environmental, physiological and trophic factors and the temporal and spatial scales of the data make it difficult to assess the role of nutrients in the proliferation of microplankton species (Glibert et al. 2005). In addition, studies in multiple environments would be useful for assessing the environmental forcing in toxin variability (Anderson et al., 2005).

\section{ACKNOWLEDGEMENTS}

The authors thank the staff of the Oceanographic Conditions Department of INTECMAR for their technical assistance and the crew of the R/V J.M. Navaz and R/V Lura. The authors also thank the staff of the Biotoxins Department of INTECMAR who supplied the historic annual reports of shellfish harvesting closures. This study was funded by INTECMAR

\section{REFERENCES}

Álvarez-Salgado X.A., Labarta U., Fernández-Reiriz M.J., Figueiras F.G., Rosón G., Piedracoba S., Filgueira R., Cabanas J.M. 2008. Renewal time and the impact of harmful algal blooms on the extensive mussel raft culture of the Iberian coastal upwelling system (NE Europe). Harmful Algae 7: 849-855.

Álvarez-Salgado X.A., Gago J., Míguez B.M., Pérez F.F. 2001. Net ecosystem production of dissolved organic carbon in a coastal upwelling system: the Ría de Vigo, Iberian margin of the North Atlantic. Limnol. Oceanogr. 46: 135-147.

Álvarez-Salgado X.A., Rosón G., Pérez F.F., Figueiras F.G., Ríos A.F. 1996. Nitrogen cycling in a estuarine upwelling system, the Ría de Arousa (NW Spain). II. Spatial differences in the short time scale evolution of fluxes and net budgets. Mar. Ecol. Prog. Ser. 135: 275-288.

Álvarez-Salgado X.A., Gago J., Míguez B.M., Gilcoto M., Pérez F.F. 2000. Surface waters of the NW Iberian margin: Upwelling on the shelf versus outwelling of upwelled waters from the Rías Baixas. Estuar. Coastal Shelf Sci. 51: 821-837.

Anderson D.M., Glibert P.M., Burkholder J.M. 2002. Harmful algal blooms and eutrophication: Nutrient sources, composition and consequences. Estuaries 25: 704-726.

Anderson D.M., Pitcher G.C., Estrada M. 2005. The comparative "systems" approach to HAB research. Oceanography 18: 148-157.

Doval M.D., Álvarez-Salgado X.A., Pérez F.F. 1997. Dissolved organic matter in a temperate embayment affected by coastal upwelling. Mar. Ecol. Prog. Ser. 157: 21-37.
Doval M.D., Nogueira E., Pérez F.F. 1998. Spatio-temporal variability of the thermohaline and biogeochemical properties and dissolved organic carbon in a coastal embayment affected by upwelling: the Ría de Vigo. J. Mar. Syst. 14: 135-150.

Doval M.D., Moroño A., Pazos Y. 2009. 2007 Galician oceanographic annual report. ISBN: 978-84-613-0956-6. INTECMAR (ed.) $431 \mathrm{pp}$.

Glibert P.M., Seitzinger S., Heil C.A., Burkholder J.M., Parrow M.W., Codispoti L.A., Kelly V. 2005. The role of eutrophication in the Global Proliferations of Harmful Algal Blooms. Oceanography 8: 198-209.

Granéli E., Carlsson P., Legrand C. 1999. The role of C, N, and P in dissolved and particulate organic matter as a nutrient source for phytoplankton growth, including toxic species. Aquatic Ecol. 33: 17-27.

Fraga F. 1967. Hidrografía de la Ría de Vigo con especial referencia a los compuestos de nitrógeno. Invest. Pesq. 31: 145-259.

Fraga F., Margalef R. 1979. Las Rías Gallegas. In: Universidad de Santiago de Compostela (ed.), Estudio y explotación del mar en Galicia. Santiago de Compostela, pp 101-121.

Hansen H.P., Grassoff K. 1983. Automated chemical analysis. In: K. Grasshoff, M. Ehrhardt and K. Kremling (eds). Methods of seawater analysis. Verlag Chemie, Weinheim, pp 347-395.

ICES WGHABD Report. 2005. ICES-IOC Working Group on Harmful Algal Bloom Dynamics Reports (WGHABD). April 2005, Norway $42 \mathrm{pp}$.

ICES WGHABD Report. 2006. ICES-IOC Working Group on Harmful Algal Bloom Dynamics Reports (WGHABD). April 2006, Poland $49 \mathrm{pp}$.

ICES WGHABD Report. 2007. ICES-IOC Working Group on Harmful Algal Bloom Dynamics Reports (WGHABD). April 2007, Latvia 49 pp.

ICES WGHABD Report. 2008. ICES-IOC Working Group on Harmful Algal Bloom Dynamics Reports (WGHABD). March 2008, Galway 49 pp.

Kudela R., Pitcher G., Probyn T., Figueiras F.G., Moita T., Trainer V. 2005. Harmful Algal Blooms in Coastal Upwelling Systems. Oceanography 8: 184-197.

Pazos Y., Moroño A., Doval M.D. 2008. 2006 Galician oceanographic annual report. ISBN: 978-84-612-9809-9. INTECMAR (ed.) 423 pp.

Prego R. 1993. Biogeochemical pathways of phosphate in a Galician ría (north-western Iberian Península). Estuar. Coastal Shelf Sci. 37: 437-451.

Prego R. 1994. Nitrogen interchanges generated by biogeochemical processes in a Galician ría. Mar. Chem. 45: 167-176.

Prego R., Barciela M.C., Varela M. 1999. Nutrients dynamics in the Galician coastal area (Northwestern Iberian Península): Do the Rías Bajas receive more nutrients salts than the Rías Altas? Cont. Shelf Res. 19: 317-334.

Smayda T.J. 1990. Novel and nuisance phytoplankton blooms in the sea: Evidence for a global epidemic. In: Graneli E., Sundström B., Edler L., Anderson D.M. (eds), Toxic Marine Phytoplankton. Elsevier, New York, Usa, pp 29-40.

Souto C., Gilcoto M., Fariña-Busto L., Pérez F.F. 2003. Modeling the residual circulation of a coastal embayment affected by wind-driven upwelling: circulation of the Ría de Vigo (NW Spain). J. Geophys. Res. 108: 3340.

Thompson M., Wood R. 1993. International Harmonized Protocol for Proficiency Testing of (Chemical) Analytical Laboratories. Journal of AOAC International 76 (4).

Wash JJ. 1991. Importance of continental margins in the marine biogeochemical cycling of carbon and nitrogen. Nature 350: 53-55.

Wollast R. 1998.Evaluation and comparison of the global carbon cycle in the coastal zone and in the open ocean. In: Brink K.H., Robinson A.R. (eds), The Sea. John Wiley, Hoboken N.Y., pp 213-252.

Wooster W.S, Bakun A., McClain D.R. 1976. The seasonal upwelling cycle along the eastern boundary of the North Atlantic. J. Mar. Res. 34: 131-141.

Received August 15, 2010. Accepted February 21, 2011.

Published online January 7, 2013. 